\title{
Analysis of Undergraduate Social Participation, Ideological and Political Education
}

\author{
Xiuhua Li \\ Liaoning Jidian Polytechnic, Dandong, 118009, China
}

\begin{abstract}
Keywords: Undergraduate, Social participation, Practical activity, Ideological and political education, Problem, problem
\end{abstract}

\begin{abstract}
Undergraduates as a young generation should participate in some education activities involving social politics, economy and cultural life in an organized way with certain goal and pertinence in accordance with the training program advocated by universities. This is also one of important approaches for China to cultivate undergraduates. It is even the basic principle of valuing undergraduate ideological and political education in the education system. Students take active part in ideological and political education activities during the university, which plays a positive role in cultivating undergraduate social practice and healthy political thought idea.
\end{abstract}

\section{Introduction}

The earliest social practical activity for Chinese undergraduates appeared in 1980 and has gained good results after 8-year spontaneous promotion, implementation and deepening. Till 1987, the central government put forward Decision about improving and enhancing ideological and political work of universities. The decision points out that undergraduates should take active part in social practice, more deeply know national conditions, true situation of socialist construction and reform and thought of people at the basic level while enhancing their cultural knowledge. Only in this way, the spirit and belief of bold innovation and dedication spirit for socialist construction can be established so as to gradually train them to useful talents for the country, party and society. Thus, undergraduate social participation ideal further deepens and promotes formation and maturity of undergraduate social practice theory. Its principle is to unite ideological and political education of the party and combine social practice experience. It aims to boost undergraduate social cognition, ideological and political quality and lay a foundation for cultivating the next generation with comprehensive quality and advanced thought for socialism.

\section{Undergraduate social practice}

\section{Social practice}

"Social practice means the subject with the help of certain intermediary means transform material activities of objective world with certain purpose". This is the definition of social practical activity mentioned in Marx's dialectical materialism epistemology. Marx considered social practice was an objectivity activity human beings should especially own and also a kind of inevitable existence mode in society. It is a progressive process of fusing and unifying subjectivity and objectivity. Indeed, the author thinks this process is also a process of ideological cognition and evolution. It exists abstractly. Therefore, social practice mentioned by Marx is a narrow concept. It purely refers to all material production activities for human to transform objective world.

\section{Undergraduate social practice}

Compared with Marx's material social practical activity, undergraduate social practical activity proposed by Chinese education is more generalized. It not just purely refers to material production activity to transform objective world. Broadly speaking, it also contains transformation, development and deepening of undergraduate political thought. Educational policy of Chinese Communist Party holds that, "undergraduates as an important group for social development walk out of campus with certain purpose and plans in an organized way, go deep among the masses and enter the grass roots. 
While knowing society and cognizing national conditions, they can improve skills, cultivate morality, train willpower and enhance sense of social responsibility and make endless efforts to make contributions to the society". Therefore, undergraduate social practice has become a key part of socialist higher education with Chinese characteristics.

\section{Relationship between social practice, ideological and political education}

During quality-oriented education reform, Chinese central government put forward the importance of undergraduate social practice. The Party Central Committee puts out that social practice can enhance undergraduate ideological and political awareness, morality and sense of social responsibility. It cannot be replaced as social practice education in terms of its value. Thus, this means undergraduate ideological and political education should include ideological and political education theory and social practice. Universities should review and implement undergraduate ideological and political education with the same vision and force. These should start form envisaging current situation of undergraduate ideological and political education. It is necessary to improve and implement undergraduate social practice education through making feedbacks to the problems. So in realistic system, ideological and political theory education and social practice should own the following relations:

Firstly, their have the same goal. Ideological and political theory education adopts book-based and infusion nature. Certain social group ideology is created through these fixed education modes. Political view, moral rules and ideology of these groups comply with education needs. Social practice means the objects of education participate in society in person and reflect what they do in ideological and political education. They transform themselves through practice and facilitate their thought and ideological understanding more mature and richer. Although the effect of social practice is much superior to theory education in a sense, their education goal is the same.

Secondly, ideological and political theory education and social practice have strong and indivisible logical relationship. With theoretical ideological and political education activity, human subjectivity may be motivated. Real objective activity is reflected in society through the subjectivity. This is a process of transforming subjectivity to objectivity and unifying subjectivity and objectivity. In social practical practice, all events in objective world proceed according to subjective will and subjective aim of objects of education. In this stage, subjective will of education objects are gradually transformed by objective facts. When those who have experienced social practice impart their experience to others, such objective awareness is conveyed through subjective will. Although the information received by the third party comes from indirect experience of education objects, it can influence more to actively participate in social practice and finally forms social practice force. People can change the society while changing themselves.

Finally, social practice is the best means to actualize abstract theory imparted in ideological and political theory education. Besides, undergraduates generally lack practicalness, initiative and enthusiasm for study. Study of political thought and other disciplines just rests on book theory. Therefore, social practice can improve undergraduate fusion in social ideological idea and boost their subjective initiative. Through practice, undergraduates can associate all abstract ideological theory and realistic social life, know political and ideological education is not just a slogan and that real valuable things should be penetrated in society. In this way, real connotation of ideological and political theory can be reflected. It can be said that the combination of ideological and political theory education and social practice is the most complete ideological and political education. They have complementary relationship and cannot be separated.

\section{Shackles of social practice of undergraduate ideology and politics}

\section{Insufficient ideological and political theory}

For undergraduate group, ideological and political education popularization is not sufficient. In numerous universities, different forms of universities fail to uniformly arrange social practice of ideological and political theory education. In other words, ideological and political education coverage of each university is different. In universities, course arrangement and daily management of 
students are loose. They have no too many strict requirements. So, except specialized courses and culture courses, universities rarely organize study of ideological and political education theory and social practice. Moreover, undergraduates have grown up. It is difficult for universities and teachers to manage undergraduates. Furthermore, many undergraduates contradict ideological and political education activity organized by universities. Generally speaking, undergraduate ideological and political education mainly depends on students' consciousness, understanding of society and ideological consciousness. Just as mentioned above, China's political and ideological education should not merely aim at undergraduate group, but also popularize in educational institutions at all levels so that students can receive healthy national ideological and political theory education since the childhood. It is better to implement social practical activity more early. In this way, students' attitude to the country and society and sense of responsibility can be corrected.

\section{Lack of perfect motivation evaluation mechanism}

In ideological and political education, regardless of theory learning and social practice, Chinese universities almost do not set up relatively perfect motivation evaluation mechanism. This related to students' lack of enthusiasm for political thought study mentioned above. On the other hand, universities fail to fully pay attention to ideological and political education. In many cases, social practice is just additional or extra learning task. There is short of initiative. Students cannot attach importance to social practice. In fact, for modern people, people have certain purpose for every thing, so such pure obligation thought should not exist in Chinese education. This does not comply with human social development attribute, especially for grown undergraduate group. Therefore, universities and teachers should guide students through some motivations or evaluation mechanisms when organizing social practical activity, such as associating students' social practice with excellence election and improving students' enthusiasm for participation in social practice.

\section{Improper form}

Compared with other grade education institutions, ideological and political education activities carried out in universality education system are many. However, the form is not very good. Every university uses the same scheme for all students. So, activities of universities lack innovation and characteristics in this aspect. This also indirectly reduces subjective initiative of undergraduates for social practice and greatly affects promotion and popularization of political thought study.

\section{Solutions}

\section{To stick to people-oriented educational idea}

Undergraduates are the main force of social development and ideological communication. Ideological and political education for undergraduates should be “people-oriented”. In other words, undergraduates should be required to participate in practical activity, learn ideological and political education and regard their will and characteristics as the root. Especially, it is necessary to implement political and ideological education and social practice in accordance with specialty features and age structure.

To reach the above, firstly, undergraduates should attach importance to social practice and be really willing to carry out social practical activities. Secondly, social practice content should be set up well. The author considers undergraduate social practice may not be always limited to community, park or street. During implementation of social practice, ideological and political education, theory and practice must be closely related so as to convince people by reasoning and touch people with true emotion, make social practice enjoy popular support and reach good education effect.

Secondly, in the opinion of the author, ideological and political education is of human education and should serve people. Thus, only when the education mode is considered from the perspectives of serving undergraduates, helping them become useful persons and their vital interests can their interest in learning political education be aroused. Hence, undergraduate ideological and political education should start from their characteristics and implement the things they want to know. Undergraduate social practical activities should be more generalized. When undergraduates do any thing beneficial to society, they actually feed back and explain ideological and political education in a perfect way, 
because these are advocated in ideological and political education. Students are expected to be valuable people making contributions to society. Thus, it is necessary to combine undergraduates' specialties, employment and social practice, make undergraduates cognize society and themselves early and naturally impart ideological and political education and social practice forms to students.

\section{To establish long-term safeguard mechanism}

Undergraduate social practice should be guaranteed by universities and society. Such guarantee should be effective, standard and sustainable. For example, universities may establish Work manual for undergraduate social practice, Study manual for university social practice, Evaluation sheet of social practice supervision and Learning plan of undergraduate social practice. The establishment of these regulations and rules pay attention to quality of undergraduate social practice process, combine undergraduate social practice process and results, review, monitor and manage them. Besides, universities can answer questions and provide help for undergraduate social practical activity through establishing undergraduate social practice guidance committee so as to systematize, systematize and normalize undergraduate social practical activities and become a required course of students during the university. If things continue this way, Chinese education system can gain good benefits from long-term benefits, i.e. undergraduates cultivate social service awareness and improve ideological and political consciousness. Chinese university education hopes to see this.

\section{Conclusion}

Actually, there are many countermeasures of undergraduate social practice, ideological and political education. But generally speaking, there is only one purpose of these countermeasures, i.e. boost ideological and political education level of Chinese undergraduates, make them actively walk to society, actively participate in social practice and make preparations for entering society after graduation. But, improving undergraduate ideological and political education level and awareness through social practical activities cannot be completed in one day. It needs a very long process and takes a long time. What we can do at present is to actively utilize social practical activities and give full play to education function of social practice so as to enhance undergraduate comprehensive quality. Time can prove this.

\section{References}

[1] Du Hongtao, Peng Yunlong, Li Hua et al., Study on ideological and political education function of undergraduate social practice. Youth \& Juvenile Research, 2008,(z1)

[2] Liu Yang, On ideological and political education in undergraduate social practice. East China Normal University, 2008

[3] Xie Hong, Exploration of undergraduate social practical activity in new period. Southwestern University of Finance and Economics, 2005 